\title{
Geographical distribution of medical graduates from a public university
}

\author{
Oscarina da Silva Ezequiel ${ }^{1 *}$, Giancarlo Lucchett ${ }^{1}$, Alessandra Lamas Granero Lucchetti ${ }^{1}$, Maria Helena Senger ${ }^{2}$, \\ lucas Braga ${ }^{3}$, Rafael lacerda ${ }^{3}$, Marlon Filippo ${ }^{3}$, Fernando Colugnati ${ }^{4}$, Danette McKinley $^{5}$, Eliana Amaral ${ }^{6}$ \\ ${ }^{1} \mathrm{MD}$, PhD, Faculdade de Medicina da Universidade Federal de Juiz de Fora (UFJF), Juiz de Fora, MG, Brazil \\ ${ }^{2} \mathrm{MD}$, PhD, Faculdade de Ciências Médicas e da Saúde, Pontifícia Universidade Católica de São Paulo (PUC-SP), São Paulo, SP, Brazil \\ ${ }^{3}$ Medical Student, Faculdade de Medicina da UFJF, Juiz de Fora, MG, Brazi \\ ${ }^{4} \mathrm{PhD}$, Faculdade de Medicina da UFJF, Juiz de Fora, MG, Brazil \\ ${ }^{5} \mathrm{PhD}$, Foundation for Advancement of International Medical Education and Research (FAIMER) \\ ${ }^{6} \mathrm{MD}$, PhD, Faculdade de Ciências Médicas da Universidade Estadual de Campinas (Unicamp), Campinas, SP, Brazil
}

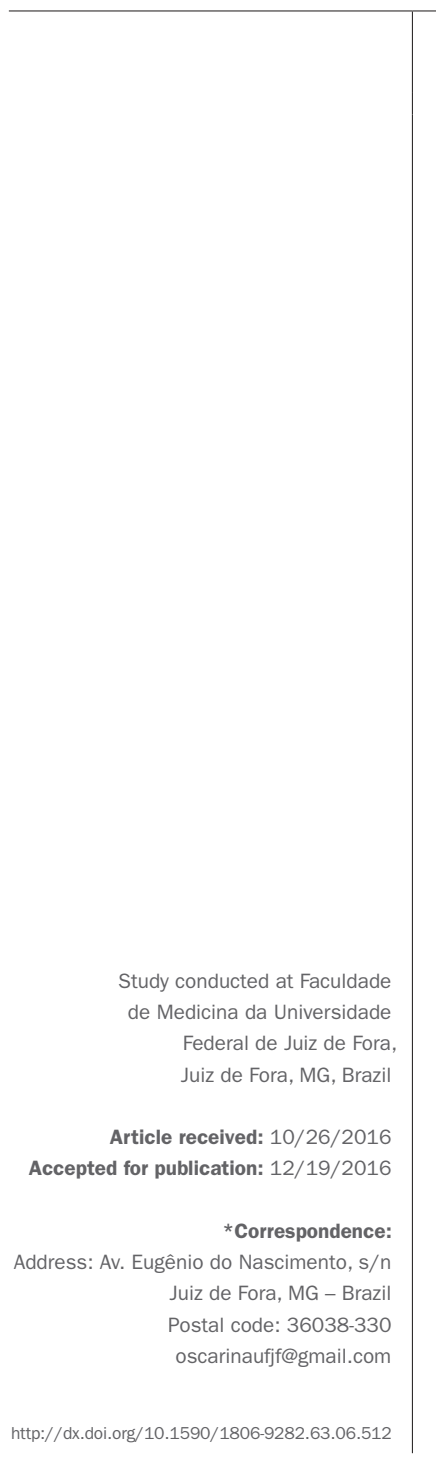

\section{SUMmARY}

Objective: To evaluate the geographic distribution and career trajectory of medical graduates and the factors associated with their choice of practice location. Method: A cross-sectional study involving graduates from December 2001 to December 2010 was conducted. A self-administered questionnaire collected demographics and geographic information (place of birth, place of residence at the time of medical school admission, place of residency training and practice location), and reason for choosing the current location. Statistical analyses assessed trends in geographic distribution of graduates, and identified factors associated with location choice (through the population density of the location chosen for professional practice).

Results: A total of 563 graduates completed the questionnaire. Of those, $4.3 \%$ $(n=24)$ reported family medicine as their medical specialty, 19.9\% $(n=112)$ reported other primary care specialties (internal medicine, pediatrics, surgery and obstetrics-gynecology) and the others chose subspecialties. Larger cities were more likely to be chosen for practice, particularly for newly-graduated doctors. Job invitations received during medical residency training increased the likelihood of choosing high-populated cities. In contrast, job invitations received during medical school increased the likelihood of choosing cities less populated. Amongst those in cities with lower population density, proximity to family members was an additional influencing factor; those who chose more densely populated cities did so because of better infrastructure and recreational options.

Conclusion: Most of the physicians included in this study pursue subspecialties training and were practicing medicine in large cities. Knowing the multiple factors that influenced the choice of practice location can assist in planning future strategies to reduce physician workforce misdistribution.

Keywords: physicians distribution, primary health care, professional practice location.

\section{INTRODUCTION}

One of the challenges of providing health care for all is distributing the physician workforce to meet the health needs of the population, including those in remote areas and living under adverse socioeconomic and geographic conditions. ${ }^{1,2}$ Besides meeting the needs of the population, there is also the goal of strengthening primary health care (PHC), since general practitioners act as gatekeepers in relation to other levels of care. ${ }^{3}$ Studies investigating the distribution of medical workforce, the allocation of re- 
sources and initiatives for locating doctors in certain areas, as well as exploring the reasons for choosing primary care, are important to identify new strategies to address these challenges. ${ }^{3,4}$

The problem of an uneven distribution of doctors is universal. Despite a gradual increase in the number of doctors in rural areas in the United States, there is still a shortage of general practitioners and specialists. ${ }^{5}$ Similarly, in Greece, a striking predominance of physicians in urban regions was also reported. ${ }^{6}$ Although there are many reasons for misdistribution, preference for specialties to the detriment of general practitioners is considered a determinant factor of this shortage in countries such as the United States, Australia, Canada and France. ${ }^{7,8}$ In fact, the number of physicians in the secondary and tertiary healthcare levels are greater than those in primary care in Spain and Brazil. ${ }^{9-11}$

In Brazil, although the health system is decentralized, physicians are primarily located in urban locations, with a high concentration in large cities. ${ }^{12}$ Since almost one quarter of Brazil's inhabitants live in rural areas in the North and Northeastern states of the country, ${ }^{13}$ recruiting physicians to practice in remote areas in Brazil is urgent in order to achieve the goals of the proposed health system. ${ }^{11,12,14}$ According to a representative survey, there were 399,692 practicing physicians in 2015 in Brazil, resulting in an approximate rate of 1.95 workers per 1,000 inhabitants. However, significant differences in the distribution of these professionals among the different regions of Brazil were observed, resulting in lower rates in the North (1.09 per 1,000 inhabitants) and Northeast (1.3 per 1,000 inhabitants) compared to the national rate, with a predominance of doctors practicing in larger cities. ${ }^{12}$

Earlier research showed that more than two-thirds of the Brazilian physicians practice in a city other than the one where they graduated and a third of them return to their hometowns. ${ }^{15}$ Attraction to larger cities was a determining factor for location choice, despite whether the physicians earned their degree at that same location or not. ${ }^{15}$ While the location of postgraduate training (i.e. medical residency) was found to affect the country's aggregate supply of physicians, medical school location did not have the same impact. ${ }^{16}$

There are complex interactions between factors contributing to geographic misdistribution and the specialty choice of health professionals. Research has shown that reasons include regional, sociocultural and economic factors, as well as personal reasons related to quality of life, individual characteristics or conditions of professional practice, such as the number of hospital beds and access to other professionals. ${ }^{1,17,18}$ Some authors classify factors affecting choice of practice location into individual (age, gender, marital status, background), organizational (job, resources, team, financial incentives) and environmental (regulation, culture, security) factors. ${ }^{1,19-23}$ The ability to provide quality services, less social isolation, professional and financial incentives are associated with the choice to practice in rural locations. ${ }^{19}$

Although there have been studies documenting the misdistribution of physicians based on practice location and specialty choice, there is little research examining the career trajectory of medical doctors and seeking to understand the determining factors for misdistribution of the workforce. ${ }^{1,2,12,21}$ Knowing the factors associated with physician career choices can help create recruitment strategies intended to promote a more equitable distribution.

Therefore, our study aimed to describe the practice locations and specialty choices of graduates from a Brazilian public medical school, and to identify associated factors.

\section{Method}

We conducted a cross-sectional study with graduates from a public medical school at the Federal University of Juiz de Fora (UFJF), Brazil. UFJF is located in the state of Minas Gerais, Southeast Brazil, which is an economically developed area in Brazil. ${ }^{13}$ All graduates from December 2001 to December 2010 were invited to participate. Those who dropped out of medical school or who were not practicing medicine were excluded (Figure 1).

The database provided by the university administration included information on 1,642 graduates. To establish initial contact, from October to December 2014, e-mails were sent to all eligible graduates inviting them to participate in the study. In order to increase the response rate, the study was promoted through social media (Facebook) and additional contacts were obtained by phone. Graduates were excluded if they could not be contacted by e-mail, phone or Facebook (Figure 1). Those who provided incomplete responses and those who did not respond after four contact attempts were excluded.

Initial contact was made between December 2014 and March 2015. The invitation contained an explanation of the research objectives and a request to send the link to an electronic questionnaire, via REDCap ${ }^{\circledR}$ (Research Electronic Data Capture). The invitation was sent through e-mail or Facebook, and contained an embedded consent form. Participation was based on electronic consent.

The self-administered questionnaire contained 55 questions, taking around 20 minutes to complete. A pilot testing with faculty members helped to improve the questionnaire and test electronic submission. 


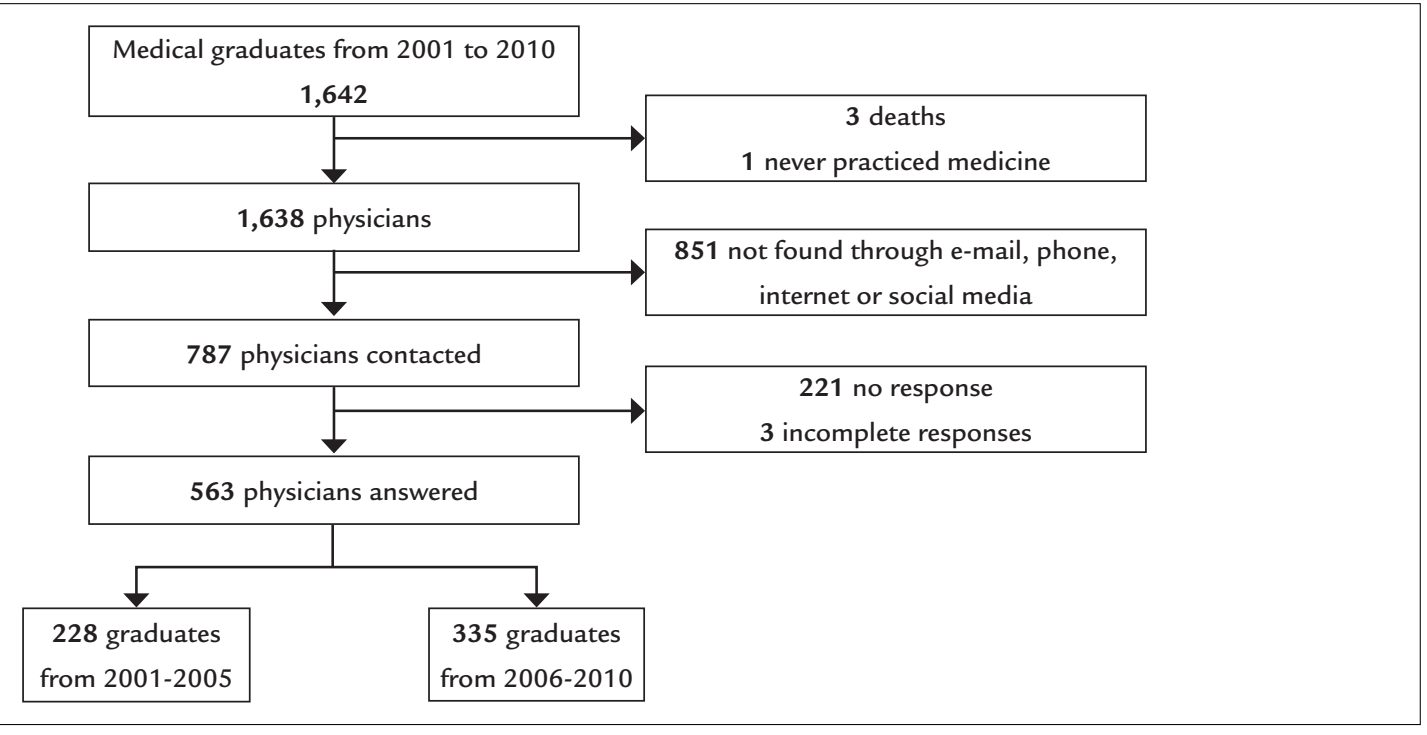

FIGURE 1 Composition of the sample of graduates from 2001 to 2010.

Data included sociodemographic characteristics (i.e., gender, age, income) and geographic location, such as place of birth, place of residence at the time of medical school admission, place of residency training and practice location; as well as reason for choosing current location. To study factors associated with choice of practice location, participants were asked to select one or more of the following reasons, checking all that applied: no reason; invitation received during medical school training; invitation received during residency training; invitation received from a family member; labor market favorable to specialty; family members lived in the city (including spouse); friends lived in the city; town with favorable educational, recreational and entertainment conditions for children and family. Participants were asked whether they completed medical residency, and if they had, they were asked which specialty they chose. The selections included family medicine, general internal medicine, general pediatrics, obstetrics-gynecology, general surgery or other specialties (i.e., cardiology, vascular surgery, and ophthalmology) and whether they worked as a faculty members.

Data were exported from REDCap to Excel for Windows and statistical analysis was performed using SPSS software version 21.0 (SPSS Inc.). Descriptive statistics (frequency, means and standard deviations) for gender, residency completion, specialty, medical teaching and income, and for variables related to place of birth, place of residence when entering medical school, medical residency location and practice location were calculated.
As it was possible that more recent graduates had not yet completed their specialty (or subspecialty) training, we divided the sample into two distinct groups based on year of graduation:

- Group 1: Those who graduated between 2001 and 2005, more likely to have completed residency and to have selected a practice location; and

- Group 2: Those who graduated between 2006 and 2010, who may still be in residency training.

Comparisons between the groups were made based on sex, residency completion, practice specialty, faculty appointment, income, and the size of the practice location using Chi-square statistics. Group comparisons based on age, density and population of the practice location used t-tests. We selected population density (people per sq. km) as our dependent variable, a proxy of development, including workforce, infrastructure and service availability. To evaluate geographic distribution of graduates, we considered the population density of place of birth, place of residence at the time of medical school admission, place of residency training and place of practice location. ${ }^{13}$

We used repeated measures analysis of variance (ANOVA) with location characteristics as the dependent variable and time (birth, medical school, residency, practice) as the independent variables. Post hoc analyses using the Bonferroni test were conducted for statistically significant ANOVA findings. Finally, we used multiple linear regression models (stepwise method) to establish the factors associated with choice of cities for 
housing in relation to population density of cities chosen for professional practice for each group.

In order to assess which factors were associated with the choice of practice location for all graduates and group 1 , we used a multiple linear regression analysis. Group 2 was not included in a separate regression analysis because these physicians may not have completed their specialty training and, therefore, their current practice location may reflect their location of training, not the choice for practice. The dependent variable was population density of the location chosen for professional practice and the independent variables were sex, age, average monthly income, residency completion, year of graduation, working in the PHC unit, and reason for choosing practice location (no reason; invitation received during medical school training; invitation received during residency training; invitation received from a family member; labor market favorable to specialty; family members lived in the city including spouse; friends lived in the city; town with favorable educational, recreational and entertainment conditions for children and family).

R2 was used to assess the adequacy of the model. We used $p<0.05$ for all analyses and the $95 \%$ confidence interval was calculated for a regression coefficient.

The Research Ethics Committee at the University Hospital/UFJF approved the project (no. 790823). An electronic consent form was signed before answering the electronic questionnaire.

\section{Results}

There were 1,642 medical graduates identified between 2001 and 2010. We excluded three individuals who died after graduating, as well as one graduate who never practiced medicine. We obtained e-mail addresses from 787 (48.05\%) professionals, and 566 responded to the questionnaire, finding three questionnaires incomplete. The final sample consisted of 563 respondents (34.4\% of 1,638 graduates; $71.5 \%$ of 787 graduates with contact information). Of the
787 graduates with contact information, 450 (79.9\%) accessed the questionnaire through a Facebook link and 113 $(20.1 \%)$ through an e-mail link. The number of respondents by year of program completion ranged from 39 (completion in 2003) to 73 (completion in 2007 or 2010).

Most graduates (86.5\%) resided in the state of Minas Gerais (state of medical school) at the time they began undergraduate medical training. Graduates were practicing in 23 of the 26 states of Brazil, with the highest concentration in the states of Minas Gerais (58.1\%), São Paulo (17.4\%) and Rio de Janeiro (11.7\%). They undertook residency training in Minas Gerais (46\%), São Paulo (20.4\%) and Rio de Janeiro (16.3\%).

Twenty-four physicians (24/4.3\%) practiced family medicine, 112 (19.9\%) practiced other primary care specialties including pediatrics, obstetrics-gynecology, internal medicine and surgery, and 427 (75.8\%) chose other specialties or subspecialties.

An analysis of all graduates showed that reasons for choosing practice location in smaller cities included family members living there $(\mathrm{p} \leq 0.001)$, the perception that the location had favorable educational opportunities $(\mathrm{p}=0.013)$, working in PHC Unit $(\mathrm{p}=0.019)$, and receiving an invitation during medical school training $(\mathrm{p}=0.003)$. For those choosing larger cities, the reasons were that the location had favorable recreational and entertainment conditions ( $p<0.001)$, having received an invitation during residency training $(\mathrm{p}=0.007)$ and in the final year of medical training $(\mathrm{p}<0.001)$ (Table 1$)$.

Since those who graduated more recently were likely to be in their location of residency training, we divided respondents based on graduation year (Table 2). Group 1 was comprised of the 228 respondents who graduated between 2001 and 2005 (40.5\%); and group 2 was composed of the 335 respondents who graduated between 2006 and 2010 (59.5\%). Those graduating earlier had higher incomes $(\mathrm{p}<0.001)$, were older $(\mathrm{p}<0.001)$, more

TABLE 1 Factors associated with choosing a practice location according to population density: All respondents.

\begin{tabular}{|c|c|c|c|c|}
\hline & B (SE) & Beta & $\mathbf{t}$ & $\mathbf{p}$ \\
\hline \multicolumn{5}{|l|}{ City density } \\
\hline Constant & $336516.4(82789.9)$ & & -4.065 & $<0.001$ \\
\hline Family members lived in the city & $-1742.2(241.4)$ & -0.286 & -7.216 & $<0.001$ \\
\hline Town with favorable recreational and entertainment conditions & $1015.3(264.7)$ & 0.172 & 3.836 & $<0.001$ \\
\hline Town with favorable educational conditions & $-676.9(270.2)$ & -0.114 & -2.505 & 0.013 \\
\hline Work in Primary Health Care Unit & $-905.9(386.5)$ & -0.098 & -2.344 & 0.019 \\
\hline Invitation received during residency training & $677.6(251.4)$ & -0.110 & 2.696 & 0.007 \\
\hline Invitation received during medical school & $-1032.8(340.8)$ & -0.119 & -3.031 & 0.003 \\
\hline Year of medical school program completion & $169.2(41.2)$ & 0.168 & 4.107 & $<0.001$ \\
\hline
\end{tabular}


TABLE 2 Socioeconomic characteristics, professional profile and size of city of residence for medical school graduates.

\begin{tabular}{|c|c|c|c|}
\hline Characteristics & Group $1(n=228)$ & Group $2(n=335)$ & \\
\hline & $N(\%)$ & N (\%) & $\mathrm{p}^{1}$ \\
\hline Sex (\%) & & & 0.001 \\
\hline Male & $131(57.7 \%)$ & $147(43.9 \%)$ & \\
\hline Female & $96(42.3 \%)$ & $188(56.1 \%)$ & \\
\hline Completed residency & & & 0.206 \\
\hline Yes & $206(91.2 \%)$ & $296(88.6 \%)$ & \\
\hline No & $20(8.8 \%)$ & $38(11.4 \%)$ & \\
\hline Medical specialty & & & 0.137 \\
\hline Primary care $^{2}$ & $60(26.5 \%)$ & $74(22.2 \%)$ & \\
\hline Other & $166(73.5 \%)$ & $260(77.8 \%)$ & \\
\hline Faculty appointment & & & $<0.001$ \\
\hline Yes & $52(23.1 \%)$ & $29(8.8 \%)$ & \\
\hline No & $173(76.9 \%)$ & $300(91.2 \%)$ & \\
\hline Income & & & $<0.001$ \\
\hline Less than $\mathrm{R} \$ 10,000.00$ & $31(14.0 \%)$ & $119(36.2 \%)$ & \\
\hline$R \$ 10,000-20,000.00$ & $113(51.1 \%)$ & $146(44.4 \%)$ & \\
\hline More than $\mathrm{R} \$ 20,000.00$ & $77(34.8 \%)$ & $64(19.5 \%)$ & \\
\hline City size - practice location & & & 0.045 \\
\hline Large & $143(63.6 \%)$ & $243(73.2 \%)$ & \\
\hline Medium & $47(20.9 \%)$ & $47(14.2 \%)$ & \\
\hline \multirow[t]{2}{*}{ Small } & $35(15.6 \%)$ & $42(12.7 \%)$ & \\
\hline & Mean (SD) & Mean (SD\%) & $\mathrm{p}^{3}$ \\
\hline Age & $36.4(1.9)$ & $31.6(2.5)$ & $<0.001$ \\
\hline Practice location population density & $1622.7(2407.0)$ & $2879.0(3144.3)$ & $<0.001$ \\
\hline Practice location population & $1,501,744.99(2,498,877.54)$ & $3,012,194.04(3,952,865.48)$ & $<0.001$ \\
\hline
\end{tabular}

likely to be male ( $\mathrm{p}=0.001)$, reported working as faculty members more often $(p<0.001)$ and lived in cities with lower population density $(\mathrm{p}<0.001)$ (Table 2$)$.

Figure 2 shows that graduates migrated from less populated cities to more populated cities during the course of their training and initial career, compared with birthplace and location of medical school. The mean population density of the birthplaces was 909.2 people per sq. $\mathrm{km}$ for group 1 and 927.4 for group 2 . In contrast, their residence at the start of medical school had lower mean population density, 466.3 people per sq. $\mathrm{km}$ for group 1 and 662.6 for group 2. Location of residency training occurred in higher density cities (mean population density: 3,093.7 people per sq. $\mathrm{km}$ of land area for group 1 and 4,074.0 for group 2).

Practice location mean population densities were lower: $1,764.3$ people per sq. $\mathrm{km}$ of land area for group 1 and 3,080.7 for group 2. Physicians who had been practic- ing longer tended to return to cities with lower density, while those who had completed their training more recently tended to report living in larger cities. There was a significant difference between the population density of cities over the course of their careers for groups 1 and 2 (within group, $\mathrm{p}<0.001$ ), as well as between groups $(\mathrm{p}<0.05)$, except for those whose birth location was a densely populated city.

The significant predictors for those graduating between 2001 and 2005 who chose smaller cities as practice locations included having family members there $(p<0.001)$ and receiving an invitation during medical school training $(\mathrm{p}=0.027)$. For those who chose larger cities, the factors identified were that the location offered better recreational activities and entertainment ( $\mathrm{p}=0.003)$, they tended to be female $(\mathrm{p}=0.012)$ and had received an invitation during residency training $(\mathrm{p}=0.009)$ (Table 3$)$. 


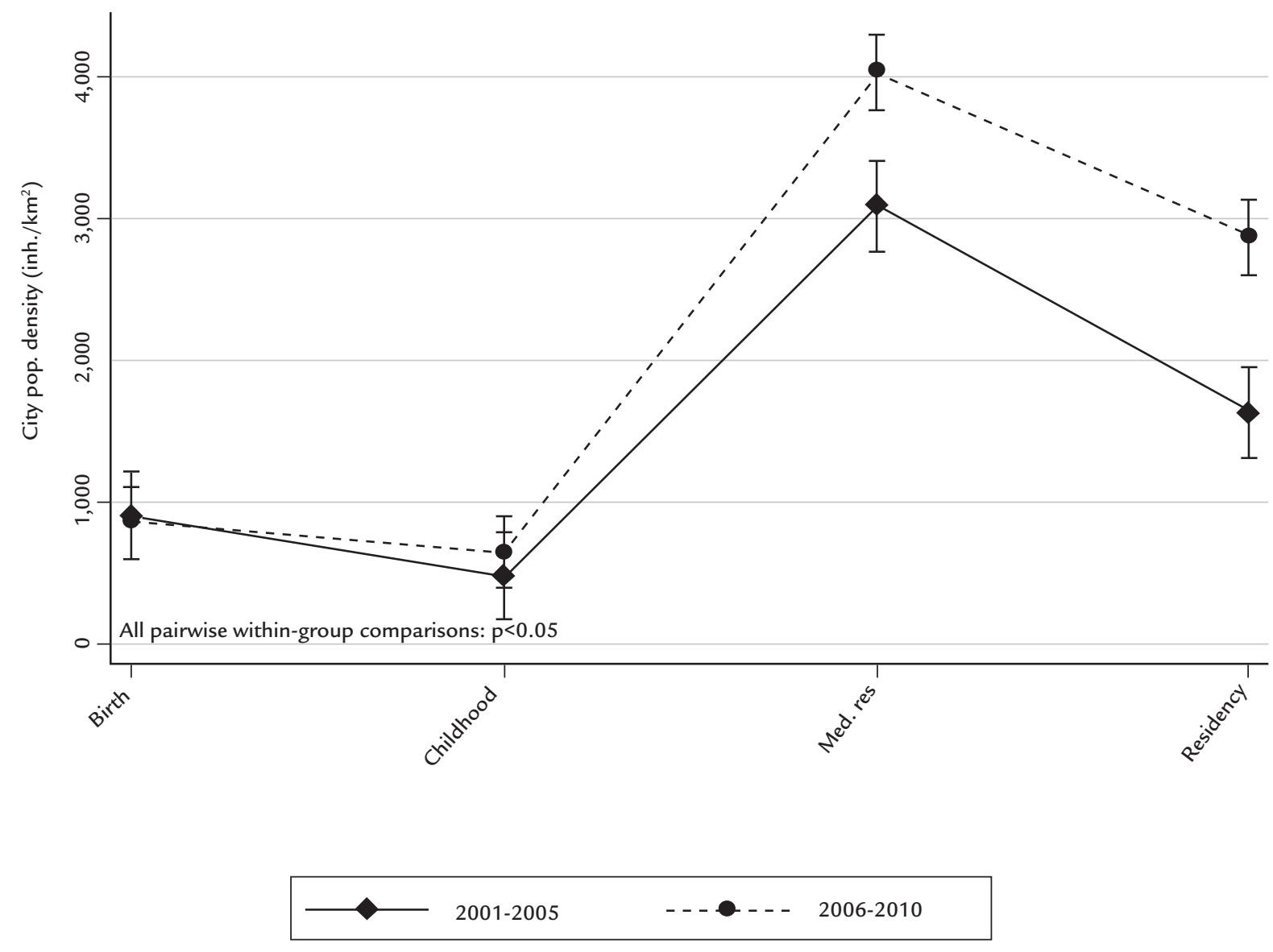

FIGURE 2 Population density of the cities chosen by graduates for living from birth to residency: (Birth) Place of birth, (Childhood) Place of residence when entering medical school, (Med. res) Place of residency training, (Residency) Place of practice location.

TABLE 3 Factors associated with choosing a practice location according to population density: Physicians that graduated between 2001 and 2005 .

B (SE)

Beta

$\mathbf{t}$

$\mathbf{p}$

\section{City density}

\section{Graduates 2001-2005}

\begin{tabular}{|c|c|c|c|c|}
\hline Constant & $370.7(533.2)$ & & 0.695 & 0.488 \\
\hline Family members lived in the city & $-1228.8(322.6)$ & 0.247 & -3.809 & $<0.001$ \\
\hline Town with favorable recreational and entertainment conditions Female & $934.9(309.4)$ & -0.193 & 3.021 & 0.003 \\
\hline Female & $798.7(314.1)$ & 0.165 & 2.543 & 0.012 \\
\hline Invitation received during residency training & $845.9(321.5)$ & 0.170 & 2.631 & 0.009 \\
\hline Invitation received during medical school & $-1047.1(469.9)$ & -0.142 & -2.228 & 0.027 \\
\hline
\end{tabular}

a $=0.399 ;$ R-square $=0.159$

${ }^{\mathrm{b}} \mathrm{R}=0.403 ; \mathrm{R}$-square $=0.163$

This model includes sex, age, average monthly income, residency completion, graduates working in PHC Unit and reasons for choosing practice location (no reason; invitation received during me dical school training; invitation received during residency training; invitation received from a family member; labor market favorable to specialty; family members lived in the city including spouse; friends lived in the city; town with favorable educational, recreational and entertainment conditions for children and family). 


\section{Discussion}

Previous publications have shown an unequal distribution of the medical workforce and sought to understand the reasons for misdistribution. In 1963, there was a substantially greater number of doctors per capita in areas of greater economic income in US urban areas. ${ }^{24}$ More recent research showed that the situation persists. ${ }^{25} \mathrm{Also}$, in Canada, there were many specialists and fewer general practitioners and family physicians practicing in areas of higher socioeconomic level. ${ }^{26}$ These results corroborate the findings of our study; larger cities were those more likely to be chosen as practice location, particularly for more recent graduates.

Factors leading to the choice of larger cities included residency training, similar to other studies in $\mathrm{Brazil}^{27}$ and the US. ${ }^{16}$ Some authors found the choice for professional practice related to the location of medical schools., ${ }^{9,28}$ In contrast, for other authors, location of medical school was not related to choice of practice location. ${ }^{16}$ Although $86.5 \%$ of the respondents were born in the state where the school was located, only $58.1 \%$ remained there after graduation, practicing mainly where they completed residency training.

Doctors with less training time tended to live in cities with greater population densities. This is probably because these professionals are still considering opportunities for employment. Perhaps, with time, this group will show the same pattern as those who graduated earlier, migrating to cities with lower population density in search of better quality of life and greater proximity to their original households. ${ }^{22,27}$ Invitation to practice in a specific location was also an important determinant of choice. When the invitation came during residency training, there was an increased likelihood for choosing larger cities, as residency programs are mostly available in these locations. In contrast, respondents invited during medical school training chose less populated cities.

As in other studies, family issues determined where to settle down, ${ }^{29,30}$ including motivation to return to less densely populated cities. ${ }^{31,32}$ On the one hand, family location attracted physicians to smaller cities; on the other hand, more entertainment opportunities influenced the choice for more densely populated cities, with better infrastructure and recreational options

In the present study, we noticed two distinct profiles in accordance with the time of graduation. First, there was a lower percentage of male doctors in the cohort graduating after 2005, corroborating with worldwide trends on feminization of the medical profession. ${ }^{2,12}$ Also, higher income was observed for the cohort of earlier graduates, probably due to the time spent in the profession.
Furthermore, the majority of physicians chose to specialize to the detriment of a primary health practice. Only a quarter of graduates opted for family medicine, general pediatrics, obstetrics-gynecology, general internal medicine and general surgery, and $90 \%$ had residency training. There was no difference between groups 1 and 2. In Britain, there is a trend toward more equitable distribution, perhaps driven by the character of the local health system, while this was not observed in Japan. ${ }^{33}$ Choosing specialties other than primary care is not surprising, since those professionals tend to have higher wages and greater increase in income over the years. ${ }^{34}$

In order to develop incentives to improve physician distribution in Brazil and increase access to PHC, many government policies have been implemented. These include more vacancies for training in medicine and residency programs, spread out at various Brazilian regions, as well as guidelines on curricular changes directing training toward PHC. ${ }^{35,36}$ However, results from the literature on the impact of these policies to attract and retain doctors remains controversial, with multiple confounding factors such as the size of the city where medical schools are located. ${ }^{1}$ The same discussion is observed in relation to different educational interventions when examined as a factor in physician workforce retention predictor in rural or underserved areas. ${ }^{17,19}$

Understanding the complex relationship between the factors that motivate doctors in their choice of workplace can help to define strategies to enhance provision of services in remote and rural areas. Studies show that the simple increase in physician supply did not reduce the distribution disparities. Thus, proposals for a better distribution of health professionals should rely on knowledge of the determining factors for choosing the place for their professional practice, which includes family composition and socioeconomic and cultural issues at the organizational level, as well as other factors related to the environment and their own training. A broad view of the multidimensional nature of choice of specialty and practice location, along with the creation of attractive conditions in remote areas, small towns and rural areas seems to be indispensable for a real change. This is an intersectorial challenge to be faced, associated with the regional development as a whole.

Our study has some limitations. We were successful in obtaining $34.4 \%$ of respondents among all graduates in the study period, $71.5 \%$ of those who could be located. It is worth noting that this fact was possible because, in addition to the more conventional method of collecting this information such as e-mail and telephone, we used 
social networking for both the request and distribution of the questionnaire. In the current investigation, $79.9 \%$ of the respondents answered the questionnaire by clicking on a Facebook link. Nevertheless, this may represent sampling bias, since participants are likely to be those with greater electronic access (e-mail and social networks). Usually, response rates based on mailed questionnaires studies reach an average of 20 to $30 \% .{ }^{9,28}$ It is likely that younger respondents in locations with better infrastructure were more likely to respond to the survey.

Despite that, our study adds to existing literature as it highlights the importance of using different media to survey and contact graduates. In addition, we examined the influence of different factors other than those commonly reported in the literature such as the invitation to work in a location at the time of medical school completion, location of residency training, and impact of the size difference between the cities of origin, medical school and residency on the distribution of physicians in Brazil.

One of the difficulties encountered in studies involving the population of graduates is access to the target population. In Brazil, it is not routine to follow them throughout their careers. Another potential limitation is that the migration of those who graduated more recently (2006 through 2010) may not yet be complete. It will be necessary to see whether this group shows similar patterns to those who have been in the workforce for a longer period of time.

\section{Conclusion}

In conclusion, our study showed that most physicians still select large cities as practice location and pursue specialist training rather than PHC. While residency and more recreational opportunities are the attractions in major urban centers, family issues and invitations at the time of medical school completion favor the choice of settling in smaller cities. These findings may help in the planning of future strategies to reduce misdistribution of the medical workforce.

\section{Resumo}

Distribuição geográfica e trajetória dos médicos egressos de instituição pública

Objetivo: Avaliar a distribuição geográfica e a trajetória dos médicos e fatores associados à escolha para o local da prática médica.

Método: Estudo transversal envolvendo graduados entre 2001 a 2010, utilizando-se questionário autoaplicado com dados sociodemográficos, informações de localização geográfica (local de nascimento, local onde residia quando entrou na faculdade de medicina, local onde realizou a residência médica e local de prática profissional), e as razões para escolha do local de sua fixação. Análises estatísticas avaliaram as tendências da distribuição dos egressos e os fatores associados com a escolha do local para a prática médica. Resultados: 563 egressos completaram o questionário. Destes, 4,3\% ( $n=24)$ eram médicos de família, 19,9\% ( $n=112)$ tinham especialidades em grandes áreas (medicina interna, pediatria, cirurgia e ginecologia-obstetrícia), enquanto os outros escolheram subespecialidades. Houve predomínio da escolha de cidades de grande porte para a prática profissional. Convites para trabalhar recebidos durante a residência médica aumentaram a escolha de cidades de maior densidade populacional. Por outro lado, os convites recebidos durante a graduação influenciaram a escolha de cidades de mais baixa densidade populacional. Para estes últimos, a presença da família no local foi fator de influência, enquanto, para os que escolheram cidades de maior densidade populacional, os fatores de influência foram melhor infraestrutura e mais opções de diversão.

Conclusão: A maioria dos médicos deste estudo fixou-se em grandes cidades e escolheu subespecialidades. Conhecer os múltiplos fatores que influenciaram a escolha do local para prática profissional pode auxiliar no planejamento de estratégias para reduzir a má distribuição do trabalho médico.

Palavras-chave: distribuição de médicos, atenção primária à saúde, área de atuação profissional.

\section{References}

1. Lehmann U, Dieleman M, Martineau T. Staffing remote rural areas in middleand low-income countries: a literature review of attraction and retention. BMC Health Serv Res. 2008; 8:19.

2. Scollan-Koliopoulos M. OECD. Health at a Glance 2011: OECD Indicators Paris: OECD Publishing; 2011.

3. Awosogba T, Betancourt JR, Conyers FG, Estapé ES, Francois F, Gard SJ, et al. Prioritizing health disparities in medical education to improve care. Ann N Y Acad Sci. 2013; 1287:17-30

4. Mason J. Review of Australian government health workforce programs. 2013.

5. Ricketts TC. Workforce issues in rural areas: a focus on policy equity. Am J Public Health. 2005; 95(1):42-8.

6. Huber M, Stanciole A, Wahlbeck K, Tamsma N, Torres F, Jelfs E, et al. Quality in and equality of access to healthcare services. Brussels, European Commission, DG Employment, Social Affairs \& Equal Opportunities. 2008:196-201.

7. Rosenblatt RA, Hart LG. Physicians and rural America. West J Med. 2000; 173(5):348

8. Jeffe DB, Whelan AJ, Andriole DA. Primary care specialty choices of United States medical graduates, 1997-2006. Acad Med 2010; 85(6):947-58.

9. Castellanos MEP, Silveira AdFMH, Martins LC, Nascimento VBd, Silva CSd, Bortollotte FHB, et al. Perfil dos egressos da Faculdade de Medicina do ABC: o que eles pensam sobre atenção primária em saúde? Arq bras ciênc saúde. 2009; 34(2):71-9. 
10. Machado MH. Os médicos no Brasil: um retrato da realidade. Rio de Janeiro: SciELO-Editora FIOCRUZ; 1997.

11. Sakai MH, Cordoni Junior L. Os egressos da medicina da Universidade Estadual de Londrina: sua formação e prática médica. Espaço para Saúde. 2004; 6(1):34-47.

12. Scheffer M. Demografia médica no Brasil: cenários e indicadores de distribuição: relatório de pesquisa-fevereiro de 2015. São Paulo: Conselho Regional de Medicina do Estado de São Paulo; 2015.

13. IBGE. Instituto de Geografia e Estatística 2015 [cited 2015 Jul. 20]. Available from: http://www.ibge.gov.br/home/estatistica/economia/comercioeservico/ pas/analisepas99.shtm\#.

14. Póvoa L, Andrade MV. Distribuição geográfica dos médicos no Brasil: uma análise a partir de um modelo de escolha locacional. Cad Saúde Pública. 2006; 22(8):1555-64.

15. Scheffer M. Demografia médica no Brasil (Vol. 2). São Paulo: Conselho Federal de Medicina e Conselho Regional de Medicina do Estado de São Paulo. 2013.

16. Whitcomb ME. New medical schools in the United States. N Eng J Med. 2010; 362(14):1255-8.

17. Rabinowitz HK, Diamond JJ, Veloski JJ, Gayle JA. The impact of multiple predictors on generalist physicians' care of underserved populations. Am J Public Health. 2000; 90(8):1225-8.

18. Wibulpolprasert $\mathrm{S}$. Inequitable distribution of doctors: can it be solved? Human Resources for Health Development Journal. 1999; 3(1):2-22.

19. Dieleman M, Kane S, Zwanikken P, Gerretsen B. Realist review and synthesis of retention studies for health workers in rural and remote areas. WHO. 2011.

20. Dussault G, Franceschini MC. Not enough there, too many here: understanding geographical imbalances in the distribution of the health workforce. Hum Resour Health. 2006; 4:12.

21. Meliala A, Hort K, Trisnantoro L. Addressing the unequal geographic distribution of specialist doctors in Indonesia: the role of the private sector and effectiveness of current regulations. Soc Sci Med. 2013; 82:30-4.

22. Wibulpolprasert S, Pengpaibon P. Integrated strategies to tackle the inequitable distribution of doctors in Thailand: four decades of experience. Hum Resour Health. 2003; 1(1):12.
23. Wilson N, Couper I, De Vries E, Reid S, Fish T, Marais BJ. A critical review of interventions to redress the inequitable distribution of healthcare professionals to rural and remote areas. Rural Remote Health. 2009; 9(2):1060.

24. Rimlinger GV, Steele HB. An economic interpretation of the spatial distribution of physicians in the US. Southern Economic Journal. 1963; 30(1):1-12.

25. Salsberg E, Grover A. Physician workforce shortages: implications and issues for academic health centers and policymakers. Acad Med. 2006; 81(9):782-7

26. Krishnan V. A macro model of change in specialty and spatial distribution of physicians in Canada, 1971-1981. Socioecon Plann Sci. 1992; 26(2):111-27.

27. Albuquerque CPd. Inequality in the distribution of rheumatologists in Brazil: correlation with local of medical residency, Gross Domestic Product and Human Development Index. Rev Bras Reumatol. 2014; 54(3):166-71.

28. Caovilla F, Leitzke L, Menezes HS, Martinez PF. Perfil do médico egresso do Curso de Medicina da Universidade Luterana do Brasil (Ulbra). Rev AMRIGS. 2008; 52(2):103-9.

29. Brooks RG, Walsh M, Mardon RE, Lewis M, Clawson A. The roles of nature and nurture in the recruitment and retention of primary care physicians in rural areas: a review of the literature. Acad Med. 2002; 77(8):790-8.

30. Hancock C, Steinbach A, Nesbitt TS, Adler SR, Auerswald CL. Why doctors choose small towns: a developmental model of rural physician recruitment and retention. Soc Sci Med. 2009; 69(9):1368-76.

31. Kristiansen IS, Førde OH. Medical specialists' choice of location: the role of geographical attachment in Norway. Soc Sci Med. 1992; 34(1):57-62.

32. Lin G, Rosenthal TC, Horwitz M. Physician location survey: self-reported and census-defined rural/urban locations. Soc Sci Med. 1997; 44(11):1761-6.

33. Matsumoto M, Inoue K, Farmer J, Inada H, Kajii E. Geographic distribution of primary care physicians in Japan and Britain. Health Place. 2010; 16(1):164-6.

34. Bodenheimer T. Primary care-will it survive? N Eng J Med. 2006; 355(9):861-4.

35. Brasil. Lei $\mathrm{N}^{\circ} 12.871$, de 22 de outubro de 2013. Programa Mais Médicos 2013 [cited 2016 Jul. 20]. Available from: http://www.planalto.gov.br/ ccivil_03/_ato2011-2014/2013/Lei/L12871.htm.

36. Brasil. Resolução n ${ }^{\circ}$ 3, de 20 de junho de 2014. Diretrizes Curriculares Nacionais do Curso de Graduação em Medicina. Ministério da Educação. 2014. 